\title{
The Potential of Fruit Coating and Film Treatments for Improving the Storage and Shelf-life Qualities of 'Gala' and 'Golden Delicious' Apples
}

\author{
Robert A. Saftner \\ U. S. Department of Agriculture, Agricultural Research Service, Horticultural Crops Quality Laboratory, \\ Beltsville Agricultural Research Center, Beltsville, MD 20705
}

AdDitional INDEX wORDs. Malus $\times$ domestica, shellac, shrink wrap, volatiles, wax

\begin{abstract}
Aвstract. The effects of harvest-applied coating and shrink-wrap polymeric film treatments of apples [Malus $\times$ domestica Borkh. 'Gala' and Mansf. 'Golden Delicious'] on volatile levels, quality attributes, respiration, and internal atmospheres after storage at $0{ }^{\circ} \mathrm{C}$ for 1 to 6 months, and during subsequent shelf life at $20{ }^{\circ} \mathrm{C}$ were investigated. Over 30 volatiles were detected, most of the identified volatiles were esters, the rest were alcohols, aldehydes, a ketone and a sesquiterpene. Shellac- and wax-based fruit coatings transiently inhibited total volatile levels in 'Golden Delicious' while not affecting those in 'Gala' apples during 6 months of storage in air at $0^{\circ} \mathrm{C}$. Holding fruit at $20^{\circ} \mathrm{C}$ for up to three weeks following cold storage increased volatile levels with coated and nontreated fruit having similar amounts. Only shellac-coated 'Golden Delicious' apples accumulated ethanol and ethyl acetate when held at $20{ }^{\circ} \mathrm{C}$. The shrink-wrap polymeric film treatment had no effect on fruit volatile levels during cold storage or during subsequent shelf life at $20^{\circ} \mathrm{C}$. Coating but not film treatments reduced respiration and ethylene production rates that were observed upon transferring the fruit to $20{ }^{\circ} \mathrm{C}$. Internal $\mathrm{CO}_{2}$ and ethylene levels increased and $\mathrm{O}_{2}$ levels decreased in coated fruit. The coating treatments led to better retention of flesh firmness in 'Golden Delicious' but not 'Gala' apples. Coating and film treatments reduced fresh weight loss in both cultivars during cold storage. The results suggest that harvest-applied coating and film treatments having relatively high permeability for $\mathrm{CO}_{2}$ and $\mathrm{O}_{2}$ and relatively low permeability for water vapor and fruit volatiles have potential for improving the storage and shelf-life qualities of 'Gala' and 'Golden Delicious' apples.
\end{abstract}

Refrigeration with or without controlled atmosphere (CA) storage is the principal technique used to retard ripening and reduce detrimental quality changes in apples (Malus $\times$ domestica) (Kader, 1992). However, both refrigeration and application of CA techniques are expensive, requiring large capital investments for installation, maintenance and energy inputs. In the Eastern U.S., it is not practical to provide equipment for CA storage of small quantities of apples of various cultivars having different optimal CA storage conditions. Moreover, once fruit are removed from storage, they are subject to ambient conditions during marketing which may increase desiccation and loss of qualityrelated volatile compounds, texture and other quality characteristics.

Alternative methods have been sought to modify the atmosphere around small quantities or individual fruit to mimic the beneficial effects of CA storage throughout the postharvest life of fruit. While fruit coatings are used commercially to improve outward appearance, fruit coating and protective film treatments also modify the internal atmosphere of fruit and, as such, have great potential as shelf life-extending treatments for apples and other fruits (Anzueto and Rizvi, 1985; Ben-Yehoshua, 1985; Kester and Fennema, 1986; Nisperos-Carriedo et al., 1990; Saftner et al., 1998). Fruit coating and film treatments function as barriers to water vapor, gases, volatile compounds and ethylene transmission (Debeaufort and Voilley, 1994; Kester and Fennema, 1986). The control of fruit deterioration by application of diffu-

Received for publication 12 Aug. 1998. Accepted for publication 30 June 1999. Use of a company name or product by the U.S. Dept. of Agriculture does not imply approval or recommendation of the product to the exclusion of others that also may be suitable. The author wishes to thank Jerry D. Cohen and Robert D. Hagenmaier for helpful suggestions and critically reviewing this manuscript, and Michele Auldridge for technical assistance and help in statistical analyses of the data. The cost of publishing this paper was defrayed in part by the payment of page charges. Under postal regulations, this paper therefore must be hereby marked advertisement solely to indicate this fact. sion barriers has been primarily but not solely attributed to altered concentrations of $\mathrm{CO}_{2}, \mathrm{O}_{2}$, ethylene, and water vapor (Banks et al., 1993; Ben-Yehoshua et al., 1983; Smith and Stow, 1984). A potential disadvantage of fruit coatings and films is for the fruit to become anaerobic with the associated development of offflavors and/or off-odors (Hagenmaier and Shaw, 1992; Kader, 1992). Currently, the commercial use of fruit coatings in apples is primarily restricted to applications for cosmetic effect, e.g., increased gloss, and reduced transpirational losses poststorage (Grant and Burns, 1994). To our knowledge, the effects of harvest-applied fruit coating and shrink-wrap film treatments on quality-associated volatile levels and fruit cavity atmospheres during subsequent storage at $0^{\circ} \mathrm{C}$ and $20^{\circ} \mathrm{C}$ has not been reported.

The objective of this study was to examine the utility of harvest-applied shellac- and wax-based coatings and a shrinkwrap polymeric film on improving the storage and shelf-life qualities of 'Gala' and 'Golden Delicious' apples.

\section{Materials and Methods}

'Golden Delicious' apples were harvested in the preclimacteric stage (ethylene production $<2 \mathrm{pmol} \cdot \mathrm{kg}^{-1} \cdot \mathrm{s}^{-1}$ and the climacteric rise in $\mathrm{CO}_{2}$ production had not yet begun; firmness $<85 \mathrm{~N}$ ) from a commercial orchard and randomized. The fruit in 120-fruit sets were hand coated $\left(0.4 \mathrm{~mL}\right.$ per fruit) at $20 \pm 1^{\circ} \mathrm{C}$ with a shellacor wax-based formulation or individually packaged with a shrinkwrap polymeric film at $20^{\circ} \mathrm{C}$. The wax coating and film were selected for their relatively high permeability for $\mathrm{CO}_{2}$ and $\mathrm{O}_{2}$ and low permeability for water vapor (Hagenmaier and Shaw, 1992) while the shellac coating was chosen as a representative commercially used coating for apples. The wax coating was prepared by R. Hagenmaier, U.S. Dept. of Agriculture (USDA)-ARS, Winter Haven, Fla.; and its exact composition was candelilla wax (16.7\%), isopropyl alcohol (2-propanol; 8.0\%), morpholine (2.1\%), oleic 
acid (cis-9-octadecanoic acid; 1.3\%) and the remainder was water. A sample of a commercially used shellac-based formulation was obtained from Elf Atochem/Decco, Monrovia, Calif., and is reported to contain water, shellac, fatty acid soaps, fastdrying solvents, and other minor ingredients. The shrink-wrap film was type LD935, 30 gauge $(\approx 8 \mathrm{~mm})$ from Cryovac, Duncan, S.C. For shrink wrapping, fruit were individually sealed in packages of the film and then shrunk with a blast of hot air $(\approx 80$ ${ }^{\circ} \mathrm{C}$ for $10 \mathrm{~s}$ ) while rotating the fruit to form a close contact with the fruit. The wrapped fruit were immediately dipped in $20 \pm 1^{\circ} \mathrm{C}$ water to avoid heat injury. Treated and nontreated (control) fruit were then stored together at $0^{\circ} \mathrm{C}$ in air for $1,2,3,4,5$ or 6 months.

Ethylene production and respiration rates of treated and nontreated fruit were monitored every $6 \mathrm{~h}$ during a 7-d period at 20 ${ }^{\circ} \mathrm{C}$ using an automated system (Izumi et al., 1996). Two five-fruit replications were measured at monthly intervals from harvest through 6 months cold storage.

At the end of 1-d, 1-, 2- and/or 3-week periods at $20{ }^{\circ} \mathrm{C}$ following 0 to 6 months cold storage, gas samples for fruit cavity volatile determinations were collected by inserting a steel hypodermic needle into the cavity through the calyx region of individually submerged fruit, then drawing 6-mL samples with a gastight syringe. Fruit cavity $\mathrm{CO}_{2}, \mathrm{O}_{2}$, and ethylene levels were also determined in gas samples collected from fruit stored $1-\mathrm{d}$ at $20^{\circ} \mathrm{C}$ following 0 to 6 months cold storage. Gas samples from five or ten identically treated fruit were analyzed for each of the seven storage periods. The levels of $\mathrm{CO}_{2}$ and $\mathrm{O}_{2}$ were measured using a gas chromatograph (GC) (model GC-3BT; Shimadzu, Kyoto, Japan) fitted with Porapak Q and Molecular Sieve 5A columns (each $\approx 2 \mathrm{~m} \times 3 \mathrm{~mm})$ and a thermal conductivity detector. Ethylene was determined with a GC (model AGC-211; Carle, Tulsa, Okla.) fitted with an alumina column $(2 \mathrm{~m} \times 3 \mathrm{~mm})$ and photoionization detector.

For analyses of fruit-cavity atmospheric volatiles, 4-mL gas samples were injected into 4-mL, air-evacuated $(13 \mathrm{~Pa})$ vials capped with teflon-lined septa. A solid-phase microextraction (SPME) (Supelco Co., Bellefonte, Pa.) fiber coated with polydimethylsiloxane (PDMS) (1 cm long, $100 \mu \mathrm{m}$ thickness) was used to collect and concentrate volatiles by virtue of its sorption characteristics (Arthur and Pawliszyn, 1990). The SPME device consisted of the retractable fiber enclosed in a metal needle. During sampling, after entering the 4-mL vial, the fiber was manually extended, volatile sorption occurred for $16 \mathrm{~min}$, then the fiber was retracted before removal from the sampling vial. The sorbed volatiles were desorbed from the fiber for $2 \mathrm{~min}$ at $250^{\circ} \mathrm{C}$ into a glass-lined, splitless injection port of a GC (5890a Series II, Hewlett Packard Co., Rockville, Md.) equipped with electronic pressure control and a flame ionization detector (FID), which was used to measure relative volatile vapor levels. The FID was calibrated routinely with a sample of 2-methylbutyl acetate. All SPME sampling was carried out at $20^{\circ} \mathrm{C} 10$ times for each treatment unless otherwise stated.

Apple volatiles were separated and identified using a procedure similar to that of Song et al., 1997. Volatiles were separated using a capillary column (HP-5, $11 \mathrm{~m} \times 0.1 \mathrm{~mm}$ id., $0.34 \mu \mathrm{m}$ coating thickness). The carrier gas was ultra purified hydrogen (6.0 research) at a flow velocity of $52 \mathrm{~cm} \cdot \mathrm{s}^{-1}$. The temperature program was isothermal for $2 \mathrm{~min}$ at $40{ }^{\circ} \mathrm{C}$ and then raised at the rate of $30{ }^{\circ} \mathrm{C} \cdot \mathrm{min}^{-1}$ to $250{ }^{\circ} \mathrm{C}$, and held for $3 \mathrm{~min}$. Injector and detector port temperatures were both $250^{\circ} \mathrm{C}$. Volatile levels are reported in relative FID area response units; calibration factors were not determined, as only relative changes were of interest.

For volatile identification, a GC-mass spectrometer (MS) procedure was used. The GC procedure was the same as described above except that ultra purified helium was used as the carrier gas. The GC/MS transfer line temperature was $250{ }^{\circ} \mathrm{C}$. Volatile detection was performed by quadrupole MS using $70 \mathrm{eV}$ electron impact ionization (5971A; Hewlett Packard Co.). Mass spectra were collected over a range of $\mathrm{m} / \mathrm{z}, 40$ to 300. Identification of volatile components was confirmed by comparison of collected mass spectra with standards and spectra in the National Institute for Standards and Technology (NIST) mass spectral library, Search Version C.01.00 (Aldrich, Milwaukee, Wis.).

Fresh weight loss, and quality attributes of firmness and

Table 1. Volatile compounds in the atmosphere of the fruit cavity and in the headspace above extracts collected from 'Gala' apples after 1-d at 20 ${ }^{\circ} \mathrm{C}$ following 1 month storage in air at $0{ }^{\circ} \mathrm{C}$.

\begin{tabular}{|c|c|c|c|}
\hline \multirow{2}{*}{$\begin{array}{l}\text { Volatile } \\
\text { compound }\end{array}$} & \multirow{2}{*}{$\begin{array}{c}\text { Retention } \\
\text { ratio }^{z}\end{array}$} & \multicolumn{2}{|c|}{ GC-FID response $\times 10^{3}$} \\
\hline & & Headspace & Atmosphere \\
\hline Ethyl acetate & 0.26 & $0.9-2.5$ & --- \\
\hline 1-Butanol & 0.34 & $5.6-10.1$ & $0.1-0.4$ \\
\hline Propyl acetate & 0.48 & $0.4-1.5$ & --- \\
\hline Unknown & 0.57 & $0.3-1.9$ & --- \\
\hline 2-Methylpropyl acetate & 0.71 & $0.4-1.5$ & --- \\
\hline Hexanal & 0.79 & $5.3-8.8$ & --- \\
\hline Butyl acetate & 0.84 & $95.2-134.0$ & $2.9-4.8$ \\
\hline trans-2-Hexenal & 0.93 & $7.6-11.9$ & --- \\
\hline 1-Hexanol & 0.98 & $13.0-19.8$ & $0.4-0.9$ \\
\hline 2-Methylbutyl acetate & 1.00 & $32.0-50.0$ & $1.0-1.7$ \\
\hline Butyl propionate & 1.06 & $0.7-2.0$ & --- \\
\hline Pentyl acetate & 1.08 & $4.4-7.4$ & $0.1-0.5$ \\
\hline Butyl butyrate & 1.23 & $3.3-6.0$ & --- \\
\hline Hexyl acetate & 1.26 & $156.2-180.2$ & $4.7-6.8$ \\
\hline Butyl hexanoate + hexyl butyrate & 1.54 & $1.5-3.5$ & $0.1-0.5$ \\
\hline 4-Allylanisole & 1.56 & $1.8-3.0$ & $0.1-0.5$ \\
\hline Hexyl 2-methylbutyrate & 1.60 & $1.8-3.0$ & --- \\
\hline Hexyl hexanoate & 1.80 & $0.5-1.0$ & $0.1-0.4$ \\
\hline
\end{tabular}

${ }^{\mathrm{z}}$ Retention time of volatile relative to retention time of 2-methylbutyl acetate. 
volatile levels from fruit extracts were determined on the same sets of treated and nontreated fruit. The fresh weight of 40 -fruit sets of treated and nontreated fruit were measured at harvest and again at monthly intervals between 1 and 6 months cold storage. The fresh weight of shrink-wrapped fruit was determined prior to packaging the fruit and after removal of the film following cold storage. Fresh weight loss is presented as a percentage of the initial fresh weight.

Fruit firmness was measured on 20-fruit sets with a manually controlled digital penetrometer (EPT-1 with an $11.1 \mathrm{~mm}$ tip; Lake City Technical Products, Kelowna, B.C., Canada) set in the Magness-Taylor mode. Firmness was measured at two opposite points on the equator of the fruit after removal of a 2-mm slice with a fixed-blade slicer at the end of an $1-\mathrm{d}$ period at $20^{\circ} \mathrm{C}$.

For volatile analyses of apple extracts, juice from unpeeled slices of individual fruit from each treatment was hand-extracted using a crimping tool. One milliliter of extract was transferred to a 4-mL vial and capped with a teflon-lined septum. The samples were quick frozen to $-20{ }^{\circ} \mathrm{C}$ and stored for up to 1 week before volatile collection. Preliminary results indicated that volatile levels were the same in crude extracts and extracts clarified by centrifugation or filtration and did not change over a 1-month storage period at $-20{ }^{\circ} \mathrm{C}$. For volatile sampling, frozen samples were thawed and equilibrated for $5 \mathrm{~min}$ at $20^{\circ} \mathrm{C}$ and then the volatiles in the headspace above the extract were collected and concentrated for 16 min onto a PDMS fiber using a SPME device described above. Apple volatiles in the headspace above crude extracts of treated and nontreated apples were separated and quantified by GC and detected and identified by GC/MS as described above. Preliminary results indicated that PDMS fibers never approached saturation during headspace sampling. Samples for volatile analyses of the headspace above extracts were collected from treated and nontreated fruit at monthly intervals from harvest through 6 months cold storage and at weekly intervals during three weeks shelf life at $20^{\circ} \mathrm{C}$ following 4 or 6 months cold storage. All SPME sampling was carried out at $20^{\circ} \mathrm{C} 10$ times for each treatment and treatment time unless otherwise stated.

Harvests were made from the same commercial orchard in 1996 and 1997. In the first year of experimentation, fruit volatile levels in the headspace above crude extracts and in the atmospheres of the fruit cavity were not determined. In the second year, all treatments described above were made.

Data were analyzed using the mixed model analysis of variance procedure (SAS Institute, Cary, N.C.). Examination of variance heterogeneity among the treatments indicated that the random experimental variance should be partitioned into two or three experimental variances. The experimental variance was generally pooled for untreated and shrink-wrapped fruit and sometimes pooled for shellac- and wax-coated fruit. Group comparisons and factoral interactions were evaluated by contrasts. The likelihood ratio test indicated that fitting the experimental variances into two or three groups was better than models for a single variance. Examination of residuals for both the two and three variance models did not indicate any concern regarding normality. The treatment means were separated at the 5\% significance level using Tukey's multiple comparison test. Unless stated otherwise, only results significant at $P \leq 0.05$ are discussed.

\section{Results}

Volatiles, mostly esters, were detected in the headspace above extracts collected from 'Gala' apples after $1 \mathrm{~d}$ at $20^{\circ} \mathrm{C}$ following
1 month storage in air at $0{ }^{\circ} \mathrm{C}$ (Table 1). Those of higher concentration were also detected in the atmosphere of the fruit cavity at levels between $3 \%$ and $4 \%$ of those detected in the headspace. Hexanal and trans-2-hexenal occurred at relatively high concentrations in the headspace but were not detected in the atmosphere of the fruit cavity. In addition to the headspace volatiles listed in Table 1, ethanol, propyl butyrate, butyl 2-methylbutyrate, 6-methyl-5-hepten-2-one, butyl2-methylbutyrate, butyl pentanoate, pentyl butyrate, hexyl pentanoate, and $\alpha$-farnesene were detected in some samples after 2 months cold storage and in most or all headspace samples collected from 'Gala' apples stored longer. Similar, albeit lower, levels of the same volatiles were present in 'Golden Delicious' fruit (data not shown).

Coating fruit with shellac- or wax-based formulations at harvest transiently inhibited total volatile levels by up to $75 \%$ in the headspace of extracts from 'Golden Delicious' apples but had a generally stimulatory effect on those from 'Gala' apples (Fig. 1) after $1 \mathrm{~d}$ shelf life at $20^{\circ} \mathrm{C}$ following 1 to 6 months cold storage. Total volatile levels in the headspace of extracts collected from shrink-wrapped fruit were similar to those in nontreated fruit. While generally not significant, total volatile levels were higher

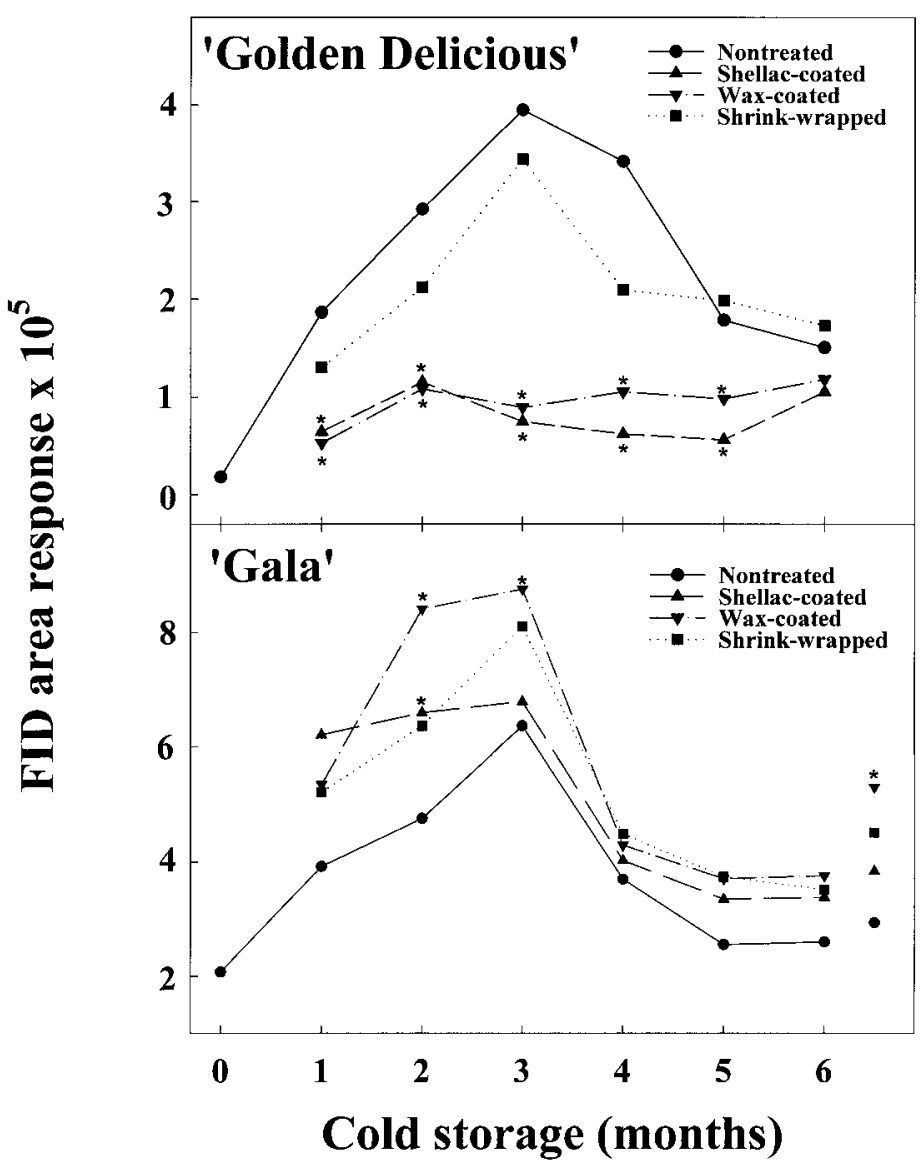

Fig. 1. Effects of coating and film treatments on total volatile levels in the headspace of extracts collected from 'Golden Delicious' and 'Gala' apples after 1- or 7-d period at $20^{\circ} \mathrm{C}$ following 0 to 6 months storage in air at $0{ }^{\circ} \mathrm{C}$. Each symbol is the mean of 10 readings from 10 individual fruit extracts. All symbols connected by lines are for volatile levels collected from fruit held for a $1-\mathrm{d}$ period at $20^{\circ} \mathrm{C}$ following the indicated periods of cold storage; the symbols not connected by lines are for volatile levels collected from fruit held at $20^{\circ} \mathrm{C}$ for a 7 -d period following 6 months of storage in air at $0^{\circ} \mathrm{C}$. For each storage period, symbols marked with an asterisk were significantly different from those in the corresponding nontreated apples by Tukey's multiple comparison test $(P \leq 0.05)$. 
in the headspace of coated and shrink-wrapped 'Gala' extracts for all storage times. Total volatile levels peaked in extracts of treated and nontreated 'Gala' apples and in shrink-wrapped and nontreated 'Golden Delicious' apples following 3 months cold storage in air. Total volatile levels in extracts from shellac- and waxcoated 'Golden Delicious' fruit did not change during cold storage. The levels of individual volatiles having FID responses of at least 2,000 followed the same pattern as those for the corresponding total volatile levels with three exceptions. In both cultivars, hexanal and trans 2-hexenal declined in film-treated and nontreated fruit and they remained stable or declined nonsignificantly in coated fruit during cold storage. Hexyl acetate levels peaked in the headspace of extracts collected from nontreated 'Golden Delicious' apples that were stored for 4 months at $0{ }^{\circ} \mathrm{C}$.

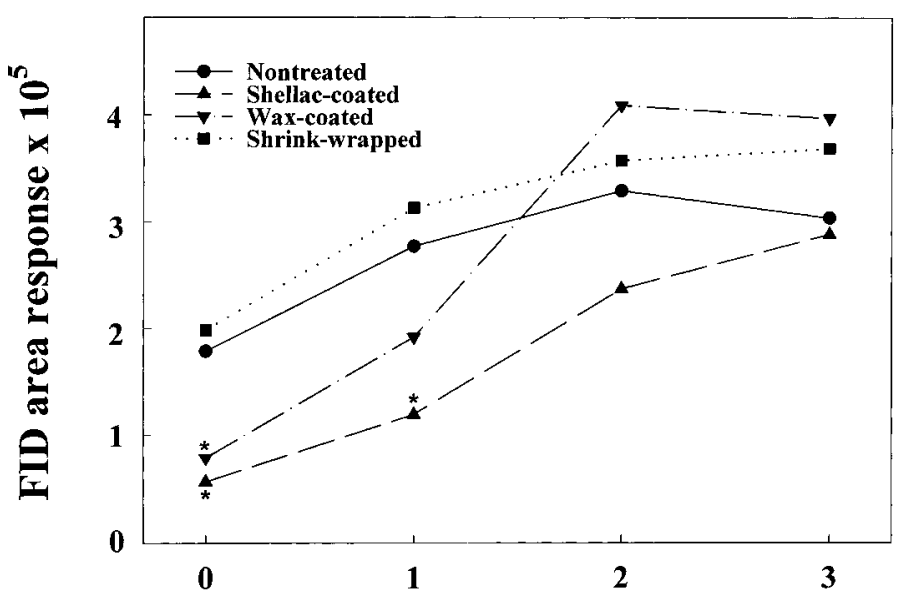

\section{$20{ }^{\circ} \mathrm{C}$ shelf-life (weeks)}

Fig. 2. Effect of coating and film treatments on total volatile levels in the headspace of extracts collected from 'Golden Delicious' apples after $1 \mathrm{~d}$ to 3 weeks at $20^{\circ} \mathrm{C}$ following 4 months storage in air at $0^{\circ} \mathrm{C}$. Each symbol is the mean of 10 readings from 10 individual fruit extracts. For each time period, symbols marked with an asterisk were significantly different from those in the corresponding nontreated apples by Tukey's multiple comparison test $(P \leq 0.05)$.

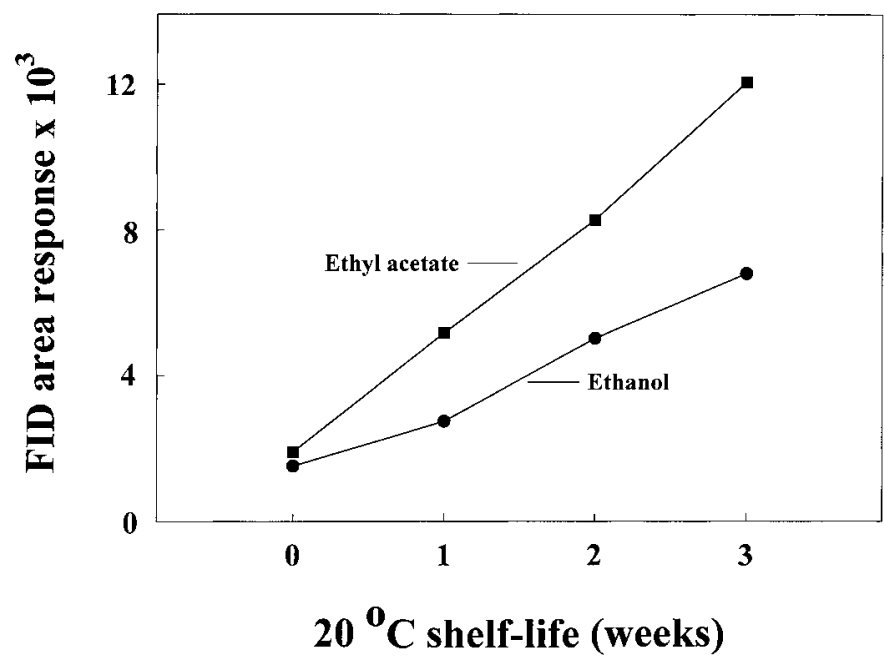

Fig. 3. Ethanol and ethyl acetate levels in the headspace of extracts collected from shellac-coated 'Golden Delicious' apples held at $20{ }^{\circ} \mathrm{C}$ for $1 \mathrm{~d}$ to 3 weeks following 4 months storage in air at $0^{\circ} \mathrm{C}$. Each symbol is the mean of 10 readings from 10 individual fruit extracts. Each volatile compound increased in level between $1 \mathrm{~d}$ and 3 weeks of shelf life at $20^{\circ} \mathrm{C}$ using Tukey's multiple comparison test $(P \leq 0.05)$.
Being the most abundant volatile in the headspace of 'Golden Delicious' extracts, this kept the total volatile level relatively high in the headspace of extracts collected from nontreated 'Golden Delicious' apples stored for 4 months at $0^{\circ} \mathrm{C}$ (Fig. 1). In 'Golden Delicious' and 'Gala' apples, ethanol and 6-methyl-5-hepten-2one began to increase in the headspace of extracts collected from fruit stored $>4$ months at $0{ }^{\circ} \mathrm{C}$ (data not shown).

Holding fruit at $20^{\circ} \mathrm{C}$ following 4 (Fig. 2) or 6 (Fig. 1) months cold storage increased the total volatile level in the headspace of both treated and nontreated fruit. Within 3 weeks at $20^{\circ} \mathrm{C}$, total volatile levels in the headspace of extracts from treated 'Gala' and 'Golden Delicious' apples were as high or higher than those in corresponding nontreated fruit. During the $20^{\circ} \mathrm{C}$ shelf life, the levels of individual volatiles having FID responses of at least 2,000 followed the same pattern as those for the corresponding total volatile levels with two exceptions. 6-Methyl-5-hepten-2one levels increased in nontreated and shrink-wrapped fruit, but not in shellac- or wax-coated apples (data not shown). In addition, ethanol and ethyl acetate levels increased in the headspace of extracts collected from shellac-coated 'Golden Delicious' apples held at $20{ }^{\circ} \mathrm{C}$ for up to 3 weeks (Fig. 3). About $10 \%$ of shellaccoated 'Golden Delicious' apples with high (FID response between $2 \times 10^{4}$ and $3 \times 10^{4}$ ) ethyl acetate levels also had reduced levels of most other volatiles resulting in nonsignificantly lower levels of total volatiles in shellac-coated 'Golden Delicious' apples held at $20^{\circ} \mathrm{C}$ for up to 3 weeks (Fig. 2). Ethanol and ethyl acetate levels did not increase in shellac-coated 'Gala' fruit or in waxed fruit of either cultivar.

Coating treatments but not shrink-wrap-film treatment reduced ('Gala') or transiently reduced ('Golden Delicious') respiration (Fig. 4) and ethylene production rates (Fig. 5) that were observed upon transferring fruit to $20^{\circ} \mathrm{C}$ following 1 to 6 months storage at $0^{\circ} \mathrm{C}$. Respiration and ethylene production rates peaked in treated and nontreated 'Gala' and in shrink-wrapped and nontreated 'Golden Delicious' apples following 3 months cold storage. Respiration and ethylene production rates in coated 'Golden Delicious' apples continued to increase during 6 months cold storage.

Fruit coating treatments modified the atmosphere in the fruit cavity (Table 2). Coating treatments increased internal $\mathrm{CO}_{2}$ and ethylene and decreased internal $\mathrm{O}_{2}$. While the internal $\mathrm{O}_{2}$ never decreased below $3 \%$, the $\mathrm{CO}_{2}$ level increased to levels in some shellac-coated 'Golden Delicious' apples where anaerobic respiration may be induced. Shrink wrap-film treatment had a similar, albeit much reduced and not always significant, effect on internal atmospheres.

'Golden Delicious' apples that were coated retained flesh firmness better during cold storage than those that were shrinkwrapped or nontreated (Fig. 6). The coating treatments were ineffective in retaining flesh firmness in 'Gala' apples (Fig. 6).

Coating or shrink wrapping fruit at harvest reduced subsequent fresh weight loss during cold storage in 'Gala' apples (Fig. 7). Shrink-wrapped fruit were the slowest at losing fresh weight followed by wax- and shellac-coated fruit. A similar pattern but somewhat greater reduction of fresh weight loss occurred in coated and film-wrapped 'Golden Delicious' apples (data not shown).

\section{Discussion}

The qualitative composition of volatiles in our studies using intact fruit cavity atmospheres and headspace analyses of apple 
extracts (Table 1) was similar to reports by other investigators using intact apple headspace and vacuum distillation methods (Dimick and Hoskin, 1983; Mattheis et al., 1998; Paillard, 1990; Song et al., 1997). However, the headspace of apple extracts contained levels of hexanal and trans 2-hexenal not usually observed in mature or ripening apples. These two aldehydes, formed by various uncontrolled enzymatic reactions when plant tissues are disrupted (Paillard, 1986), have been identified as among the most important components of apple-like odor in 'Delicious' apples (Flath et al., 1967). As with volatile analyses of fresh tomato (Lycopersicon esculentum Mill.) (Baldwin et al., 1991), mango (Mangifera indicia L.) (Malundo et al., 1997) and other fruits and vegetables (Buttery, 1993), use of apple extracts is recommended for headspace volatile studies since it more closely represents chewed fruit pulp when an apple is eaten rather than whole apples. Most of the volatiles identified in 'Gala' and 'Golden Delicious' apple extracts were esters, the rest of the identified volatiles were alcohols, a ketone, a sesquiterpene and aldehydes.

The use of shellac- and wax-based coatings or a shrink wrapfilm treatment in refrigerated air storage as potential alternatives to CA storage is an appealing proposal, offering a potential extension of storage life in apples over air storage. In 'Golden Delicious' apples, shellac- and wax-based coatings delayed ripening as indicated by better retention of fresh weight and flesh

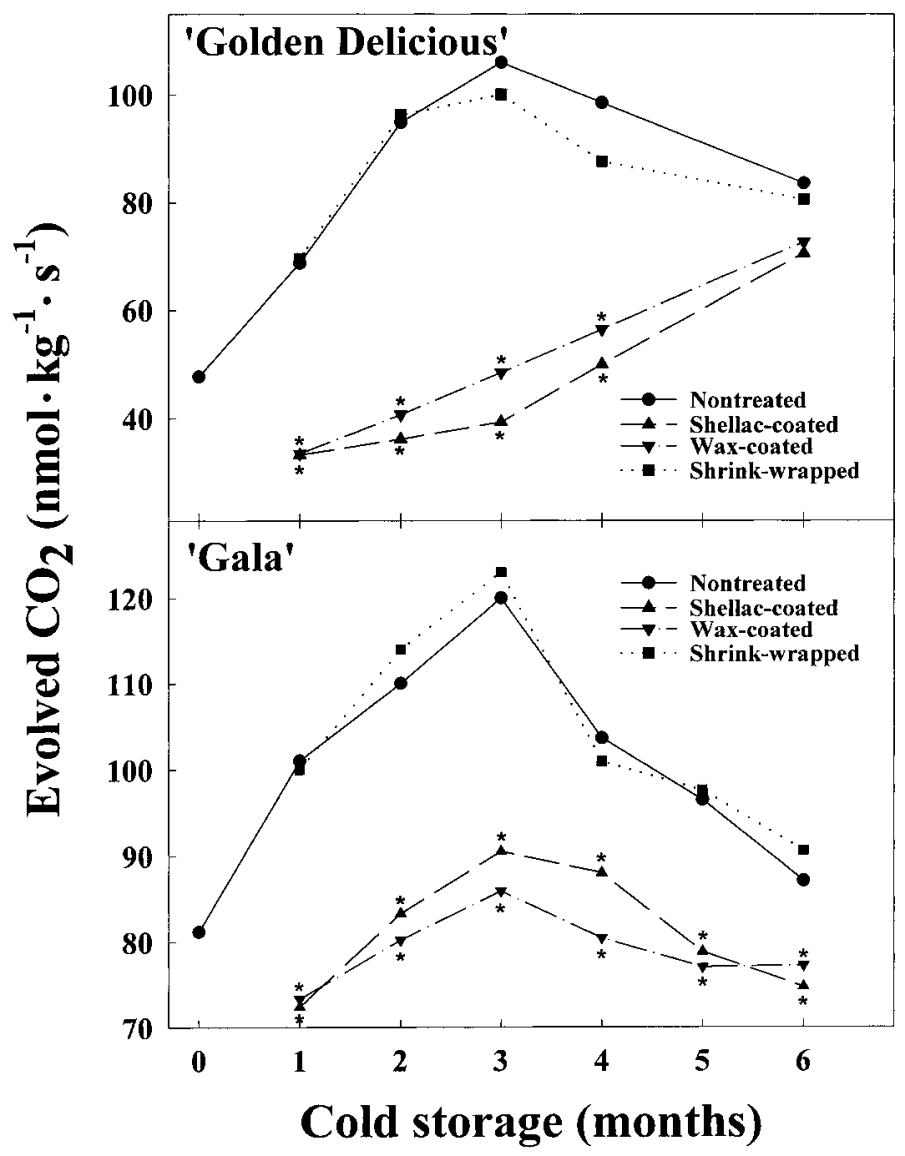

Fig. 4. Evolved carbon dioxide values of 'Golden Delicious' and 'Gala' apples during a 7 -d period at $20^{\circ} \mathrm{C}$ immediately after 0 to 6 months storage in air at $0^{\circ} \mathrm{C}$. Each symbol is the mean of 96 readings collected over a 7-d period from each of two five-fruit replications from two experiments. For each storage period, symbols marked with an asterisk were significantly different from those in the corresponding nontreated apples by Tukey's multiple comparison test $(P \leq 0.05)$. firmness, by lowered total volatile levels during storage, and the reduced respiration and ethylene production rates that were observed upon transferring the fruit to $20^{\circ} \mathrm{C}$. Further, while shellac and wax coatings reduced total volatile levels in 'Golden Delicious' fruit during cold storage, coated fruit contained more total aromatic volatiles than nontreated fruit at harvest, and holding coated fruit at $20{ }^{\circ} \mathrm{C}$ led to a full recovery of the volatile levels. The film treatment also reduced fresh weight loss in 'Golden Delicious' apples but had no other effects on fruit quality.

The coating treatments may have improved the storage and shelf-life qualities of 'Golden Delicious' apples by restricting gas migration out of the fruit. Both shellac- and wax-coating 'Golden Delicious' apples decreased internal $\mathrm{O}_{2}$ by $>50 \%$ and increased $\mathrm{CO}_{2}$ levels as much as 7-fold during storage (Table 2). With $\mathrm{CO}_{2}$ concentrations at or above $6 \mathrm{kPa}$, such as those measured in shellac- and wax-coated fruit in this study, can reduce fruit respiration, ethylene biosynthesis and action, and volatile production, and increase retention of firmness and other qualityassociated characteristics (Kader, 1986; Streif and Bangerth, 1988; Zagory and Kader, 1989). By inference, the quality characteristics of 'Golden Delicious' apples affected by shellac and wax coatings measured in this study may be attributed, at least in part, to increased fruit-cavity $\mathrm{CO}_{2}$ levels. Interestingly, ethylene levels in the fruit cavity atmosphere of coated 'Golden Delicious'

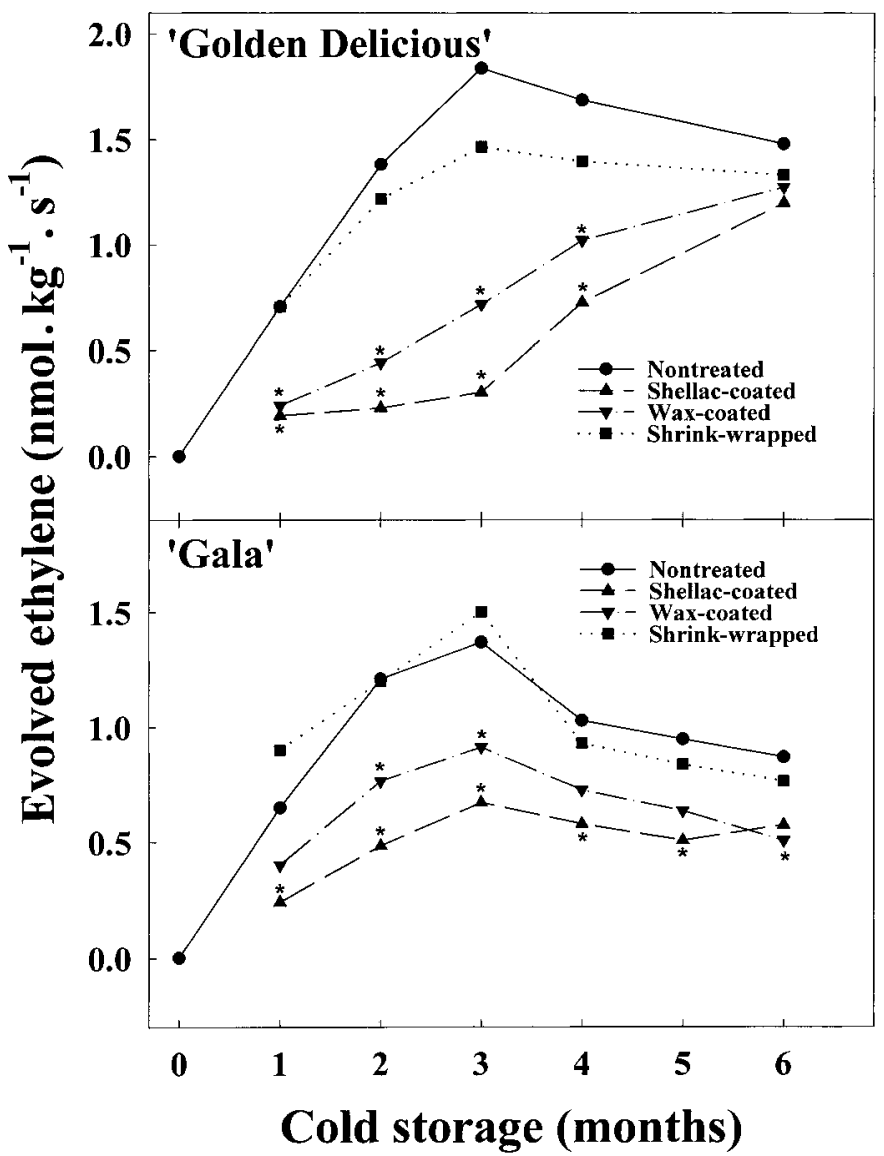

Fig. 5. Evolved ethylene values of 'Golden Delicious' and 'Gala' apples during a 7 -d period at $20^{\circ} \mathrm{C}$ immediately after 0 to 6 months storage in air at $0{ }^{\circ} \mathrm{C}$. Each symbol is the mean of 96 readings collected over a 7-d period from each of two five-fruit replications from two experiments. For each storage period, symbols marked with an asterisk were significantly different from those in the corresponding nontreated apples by Tukey's multiple comparison test $(P \leq 0.05)$. 
Table 2. Internal carbon dioxide, oxygen and ethylene levels of 'Golden Delicious' and 'Gala' apples after 1 - $\mathrm{d}$ at $20^{\circ} \mathrm{C}$ following 1 to 6 months storage in air at $0{ }^{\circ} \mathrm{C}$.

\begin{tabular}{|c|c|c|c|}
\hline Treatment & $\begin{array}{c}\mathrm{CO}_{2}^{\mathrm{z}} \\
(\mathrm{kPa} \pm \mathrm{SE})\end{array}$ & $\begin{array}{c}\mathrm{O}_{2}^{\mathrm{z}} \\
(\mathrm{kPa} \pm \mathrm{SE})\end{array}$ & $\begin{array}{c}\mathrm{C}_{2} \mathrm{H}_{4}{ }^{\mathrm{z}} \\
(\mathrm{Pa} \pm \mathrm{SE})\end{array}$ \\
\hline \multicolumn{4}{|l|}{ Gala } \\
\hline Nontreated & $1.6 \pm 0.1 \mathrm{a}$ & $19.2 \pm 0.1 \mathrm{a}$ & $4.6 \pm 0.6 \mathrm{a}$ \\
\hline Shellac-coated & $11.3 \pm 1.0 \mathrm{c}$ & $10.0 \pm 0.7 \mathrm{~d}$ & $16.8 \pm 1.4 \mathrm{~b}$ \\
\hline Wax-coated & $8.6 \pm 0.4 \mathrm{c}$ & $12.6 \pm 0.3 \mathrm{c}$ & $22.0 \pm 2.5 b$ \\
\hline Shrink wrapped & $2.9 \pm 0.1 \mathrm{~b}$ & $18.4 \pm 0.3 b$ & $4.8 \pm 0.6 \mathrm{a}$ \\
\hline \multicolumn{4}{|l|}{ Golden Delicious } \\
\hline Nontreated & $2.9 \pm 0.1 \mathrm{a}$ & $17.7 \pm 0.1 \mathrm{a}$ & $10.7 \pm 0.9 \mathrm{a}$ \\
\hline Shellac-coated & $16.9 \pm 0.6 \mathrm{c}$ & $6.1 \pm 0.4 b$ & $28.3 \pm 2.7 b$ \\
\hline Wax-coated & $13.9 \pm 0.6 \mathrm{c}$ & $7.8 \pm 0.4 b$ & $31.2 \pm 2.7 \mathrm{~b}$ \\
\hline Shrink wrapped & $3.6 \pm 0.1 \mathrm{~b}$ & $17.5 \pm 0.2 \mathrm{a}$ & $12.2 \pm 0.9 \mathrm{a}$ \\
\hline
\end{tabular}

${ }^{\mathrm{z}} \mathrm{All}$ data are reported as the mean $\pm \mathrm{SE}$ of 60 atmospheric readings from 60 individual fruit (from two experiments) held $1 \mathrm{~d}$ at $20{ }^{\circ} \mathrm{C}$ following 1 to 6 months storage in air at $0^{\circ} \mathrm{C}$. For each cultivar, means in a column followed by the same letter are not significantly different by Tukey's multiple comparison test $(P \leq 0.05)$.

apples, compared to nontreated and shrink-wrapped fruit, were higher (Table 2) even though the same fruit had reduced ethylene production rates (Fig. 5). One probable explanation for this finding is that the coatings were additionally inhibiting the out migration of ethylene and possibly other volatiles from the fruit. Coatings can act as barriers not only to gas transfer but also to water vapor and other volatile transfers (Debeaufort and Voilley,

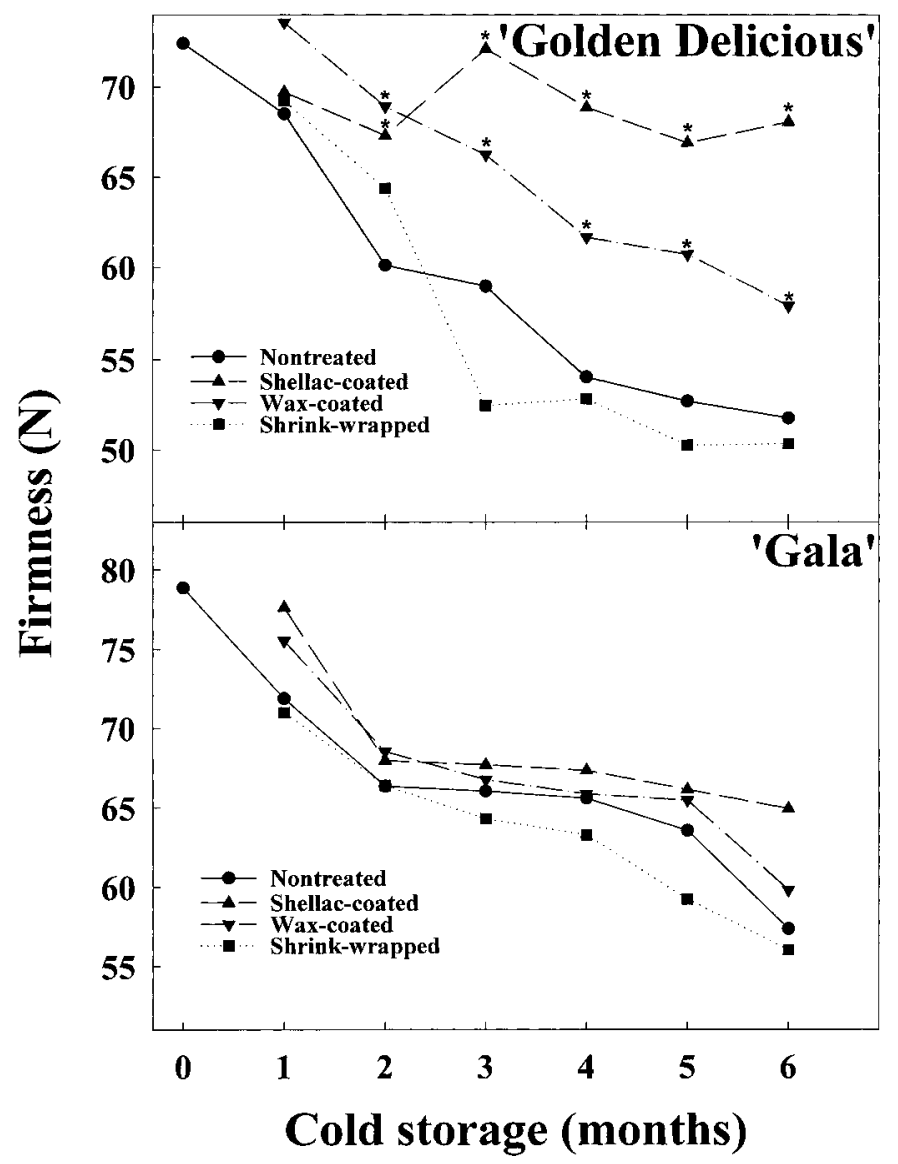

Fig. 6. Firmness in 'Golden Delicious' and 'Gala' apples after $1 \mathrm{~d}$ at $20^{\circ} \mathrm{C}$ following 0 to 6 months storage in air at $0{ }^{\circ} \mathrm{C}$. Each value of firmness is the mean of 80 readings from 40 fruit from two experiments. For each storage period, symbols marked with an asterisk were significantly different from those in the corresponding nontreated apples by Tukey's multiple comparison test $(P \leq 0.05)$.
1994). Fruit coatings have previously been suggested to enhance the quality of processed product by retention of volatiles within the coated fruit before juicing (Nisperos-Carriedo et al., 1990). Regardless of the mechanisms involved, shellac- and wax-based coatings improved the storage and delayed ripening in 'Golden Delicious' apples. The film treatment also improved the storage of 'Golden Delicious' apples as indicated by reduction of fresh weight loss but other shelf-life quality characteristics were not affected (Figs. 1, 4-6).

Shellac- and wax-based coatings were not as effective at improving storage and delaying ripening in 'Gala' apples as they were in 'Golden Delicious' apples. The coatings were roughly only half as effective at inhibiting respiration (Fig. 4), ethylene production rates (Fig. 5), and altering internal $\mathrm{O}_{2}$ and $\mathrm{CO}_{2}$ levels (Table 2) in 'Gala' versus 'Golden Delicious' apples, at least during the preclimacteric and early postclimacteric stages of fruit development. In addition, coated 'Gala' apples did not show increased retention of firmness (Fig. 6) or reduced volatile levels (Fig. 1) during storage and ripening as in coated 'Golden Delicious' apples. One plausible explanation for differential effectiveness of coating treatments in the cultivars is that gas exchange in coated fruit was higher across the less dense and thinner cuticle of 'Gala' than of 'Golden Delicious' fruit. Alternatively, large differences in cuticular surface structure between 'Gala' and 'Golden Delicious' apples may also have contributed to differences in the uniformity and effectiveness of the coating treatments between the two cultivars. While less effective, shellacand wax-based coatings still reduced respiration, ethylene production rates and fresh weight loss while fully retaining volatile levels in 'Gala' apples during cold storage and shelf life at $20^{\circ} \mathrm{C}$.

Unfortunately, the application of fruit coatings and films, like CA storage, is not without its risks. A major disadvantage of fruit coatings and films is the potential for the fruit to become anaerobic with the associated development of off-flavors (Hagenmaier and Shaw, 1992). Carbon dioxide concentrations, especially those above $15 \mathrm{kPa}$, may induce anaerobic respiration with associated ethanol and ethyl acetate accumulation, increase the incidence of physiological disorders such as surface pitting and core flush of apples, and inhibit or otherwise alter acid metabolism (Kader, 1986). While shellac-coated 'Golden Delicious' apples began to accumulate ethanol and ethyl acetate when transferred to $20^{\circ} \mathrm{C}$ (Fig. 3), no physiological disorders were observed and informal tasting during sampling periods by two laboratory personnel indicated a less sweet taste but one without 


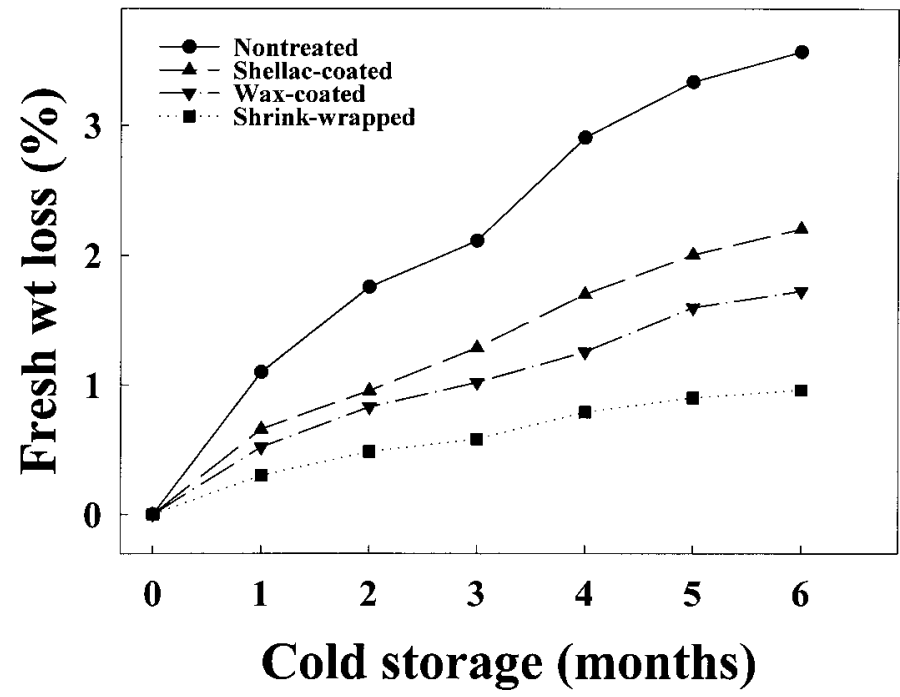

Fig. 7. Fresh weight loss in 'Gala' apples without and with a shellac- or wax-based coating or a shrink-wrap film during cold storage at $0^{\circ} \mathrm{C}$. Each symbol is the mean of 40 readings from 40 individual fruit. For each storage period, all symbols were significantly different from one another by Tukey's multiple comparison test $(P \leq 0.05)$.

off-flavors (Robert Saftner, unpublished data). The less sweet taste may have resulted from a better retention of titratable acidity during cold storage in coated than in nontreated 'Golden Delicious' apples (Saftner et al., 1998).

When using films and coatings, the degree of atmospheric modification in the fruit is dependent, all other factors being constant, on the type and thickness of material used (Smith et al, 1987). The wax-based coating and film treatments used in this study were selected for their relatively high permeability for $\mathrm{O}_{2}$ and $\mathrm{CO}_{2}$ and low permeability for water vapor compared with a number of other surface treatments (Hagenmaier and Shaw, 1992) and for their expected low permeability for quality-related volatiles (Debeaufort and Voilley, 1994; Nisperos-Carriedo et al., 1990). The shellac-based coating was commercially developed to increase outward appearance, e.g., increased gloss of fresh-market apples, not for high permeability for $\mathrm{CO}_{2}$ and $\mathrm{O}_{2}$ and low permeability for water vapor. In addition, fruit were hand coated with a minimal quantity of coating material in this study rather than being dipped in the coating material to acquire a relatively thin and uniform coating of the fruit. To reduce the risks of inducing anaerobic respiration, various physiological disorders, and off-flavors in surface-treated fruit, the results of this study would suggest that coating and film formulations and application procedures must be selected to maximize $\mathrm{CO}_{2}$ (and $\mathrm{O}_{2}$ ) permeability while at the same time maintaining commercially acceptable characteristics of gloss and low water vapor permeability. While shellac-coated fruit had higher gloss by outward appearance than waxed fruit used in this study, waxcoated fruit generally had a lower internal $\mathrm{CO}_{2}$ level than shellaccoated fruit. Since the degree of internal atmospheric modification is dependent upon the thickness of the coating used (Smith et al., 1987), it is not unreasonable to speculate that application of a diluted shellac formulation as is sometimes used by the pear industry would result in apples with increased gloss and a finish thin enough to minimize the risks of inducing altered metabolism and the associated development of off-flavors and off-odors.

While reducing the risks of altered metabolism and associated reduction of shelf-life quality remains a primary concern in working with surface coatings and films, fruit coatings and films offer some potential benefits not already stated. Concentrations of $\mathrm{CO}_{2}$ above $10 \mathrm{kPa}$, as were often present inside coated fruit during cold storage in this study, inhibit the growth of major postharvest decay pathogens, reduce apple scald in scald-sensitive cultivars, and reduce mycotoxin production in apples caused by Penicillium expansum Link (El-Goorani and Sommer, 1981; Kader, 1986). In addition, fruit coatings provide an appropriate medium for the application of approved food additives, fungicides and natural antagonists of postharvest pathogens (Bauchot and John, 1996; Cuppett, 1994). Those findings and the results of this study show that shellac-and wax-based fruit coatings may have the potential to control postharvest pathogens, extend storage and maintain various shelf-life-quality characteristics while not adversely affecting volatile levels or other quality characteristics when used in conjunction with current commercial cold storage conditions and a holding period at $20^{\circ} \mathrm{C}$ of several weeks or longer.

\section{Literature Cited}

Anzueto, C.R. and S.S.H. Rizvi. 1985. Individual packaging of apples for shelf-life extension. J. Food Sci. 50:897-905.

Arthur, C.L. and J. Pawliszyn. 1990. Solid-phase microextraction with thermal desorption using fused-silica optical fibers. Anal. Chem. 62:2145-2148.

Baldwin, E.A., M.O. Nisperos-Carriedo, and M.G. Moshonas. 1991. Quantitative analysis of flavor and other volatiles and for certain constituents of two tomato cultivars during ripening. J. Amer. Soc. Hort. Sci. 116:265-269.

Banks, N.H., B.K Dadzie, and D.J. Cleland. 1993. Reducing gas exchange of fruits with surface coatings. Postharvest Biol. Technol. 3:269-284.

Bauchot, A.D. and P. John. 1996. Scald development and the levels of $\alpha$ farnesene and conjugated triene hydroperoxides in apple peel after treatment with sucrose ester-based coatings in combination with foodapproved antioxidants. Postharvest Biol. Technol. 7:41-49.

Ben-Yehoshua, S. 1985. Individual seal-packaging of fruits and vegetables in plastic film-A new postharvest technique. HortScience 20:32-37.

Ben-Yehoshua, S., B. Shapiro, Z.E. Chen, and S. Lurie. 1983. Mode of action of plastic film in extending life of lemon and bell pepper fruits by alleviation of water stress. Plant Physiol. 73:87-93.

Buttery, R.G. 1993. Quantitative and sensory aspects of flavor of tomato and other vegetables and fruits, p. 260-286. In: T.E. Acree and R. Teranishi (eds.). Flavor science: sensible principles and techniques. American Chemical Society, Washington, D.C.

Cuppett, S.L. 1994. Edible coatings as carriers of food additives, fungicides and natural antagonists, p. 121-137. In: J.M. Krochta, E.A. Baldwin, and M.O. Nisperos-Carriedo (eds.). Edible films and coatings to improve food quality. Technomic Publ. Co., Lancaster, Pa.

Debeaufort, F. and A. Voilley. 1994. Aroma compounds and water vapor permeability of edible films and polymeric packaging. J. Agr. Food Chem. 42:2871-2875.

Dimick, P.S. and J.C. Hoskin. 1983. Review of apple flavor-State of the art. CRC Crit. Rev. Food Sci. Nutr. 18:387-409.

El-Goorani, M.A. and N.F. Sommer. 1981. Effects of modified atmospheres on postharvest pathogens of fruits and vegetables. Hort. Rev. 3:412-461.

Flath, R.A., D.R. Black, D.G. Guadagni, W.H. McFadden, and T.H. Schultz. 1967. Identification and organoleptic evaluation of compounds in Delicious apple essence. J. Agr. Food Chem. 15:29-35.

Grant, L.A. and J. Burns. 1994. Application of coatings, p. 189-200. In: J.M. Krochta, E.A Baldwin, and M.O. Nisperos-Carriedo (eds.). Edible coatings and films to improve food quality. Technomic Publ. Co., Lancaster, Pa.

Hagenmaier, R.D. and P.E. Shaw. 1992. Gas permeability of fruit coating waxes. J. Amer. Soc. Hort. Sci. 117:105-109. 
Izumi, H., A.E. Watada, and W. Douglas. 1996. Optimum $\mathrm{O}_{2}$ and $\mathrm{CO}_{2}$ atmospheres for storing broccoli florets at various temperatures. J. Amer. Soc. Hort. Sci. 121:127-131.

Kader, A.A. 1986. Biochemical and physiological basis for effects of controlled and modified atmospheres on fruits and vegetables. Food Technol. 40:99-100, 102-104.

Kader, A.A. 1992. Modified atmospheres during transport and storage, p. 85-92. In: A.A. Kader (ed.). Postharvest technology of horticultural crops. Univ. Calif., Oakland, Calif.

Kester, J.J. and O.R. Fennema. 1986. Edible films and coatings; A review. Food Technol. 42:47-59.

Malundo, T.M.M., E.A. Baldwin, M.G. Moshonas, R.A. Baker, and R.L. Shewfelt. 1997. Method for the rapid headspace analysis of mango (Mangifera indica L.) homogenate volatile constituents and factors affecting quantitative results. J. Agr. Food Chem. 45:2187-2194.

Mattheis, J.P., D.A. Buchanan, and J.K. Fellman. 1998. Volatile compounds emitted by 'Gala' apples following dynamic atmosphere storage. J. Amer. Soc. Hort. Sci. 123:426-432.

Nisperos-Carriedo, M.O., P.E. Shaw, and E.A. Baldwin. 1990. Changes in volatile flavor compounds of pineapple orange juice as influenced by the application of lipid and composite films. J. Agr. Food Chem. 38:1382-1387.

Paillard, N.M.M. 1986. Evolution of the capacity of aldehyde production by crushed apple tissues, during an extended storage of fruits. Proc. 4 th Intl. Flavor Conf. Dev. Food Sci. 12: 369-378.

Paillard, N.M.M. 1990. The flavour of apples, pears and quinces, p. 141. In: I.D. Morton and A.J. MacLeod (eds.). Food flavours. Part C: The flavour of fruits. Elsevier Science, New York.

Saftner, R.A., W.S. Conway, and C.E. Sams. 1998. Effects of postharvest calcium and fruit coating treatments on postharvest life, quality maintenance, and fruit-surface injury in 'Golden Delicious' apples. J. Amer. Soc. Hort. Sci. 123:294-299.

Smith, S., J. Geeson, and J. Stow. 1987. Production of modified atmospheres in deciduous fruits by the use of films and coatings. HortScience 22:772-776.

Smith, S.M. and J.R. Stow. 1984. The potential of a sucrose ester coating material for improving the storage and shelf-life qualities of Cox's Orange Pippin apples. Ann. Appl. Biol. 104:383-391.

Song, J., B.D. Gardner, J.F. Holland, and R.M. Beaudry. 1997. Rapid analysis of volatile flavor compounds in apple fruit using SPME and GC/ time-of-flight mass spectrometry. J. Agr. Food Chem. 45:1801-1807.

Streif, J. and F. Bangerth. 1988. Production of volatile aroma substances by 'Golden Delicious' apple fruits after storage for various times in different $\mathrm{CO}_{2}$ and $\mathrm{O}_{2}$ concentrations. J. Hort. Sci. 63:193-199.

Zagory, D. and A.A. Kader. 1989. Quality maintenance in fresh fruits and vegetables by controlled atmospheres. ACS Symp. Ser. 405:174-188. 